\title{
Effect of Employee Engagement on Organisation Performance in Kenya's Horticultural Sector
}

\author{
Brenda Beryl Achieng Otieno ${ }^{1}$, Esther Wangithi Waiganjo ${ }^{1} \&$ Agnes Njeru $^{1}$ \\ ${ }^{1}$ School of Human Resource Development, Jomo Kenyatta University of Agriculture \& Technology, Nairobi, Kenya \\ Correspondence: Brenda Beryl Achieng Otieno, Business Administration, School of Human Resource Development, \\ Jomo Kenyatta University of Agriculture \& Technology, Nairobi, Kenya. E-mail: achieng1573@gmail.com
}

Received: February 2, 2015

Accepted: February 26, $2015 \quad$ Online Published: March 5, 2015

doi:10.5430/ijba.v6n2p77

URL: http://dx.doi.org/10.5430/ijba.v6n2p77

\begin{abstract}
The horticulture sector is estimated to employ over 50,000-60,000 people directly and 500,000 people indirectly through affiliated services to the industry for example farm inputs, transport, packaging and banking (Kenya Flower Council, 2010). It is therefore imperative that the welfare of the workers working in this sector is given paramount importance by both government and the stakeholders as a whole. This study therefore sought to explore the effect of employee engagement on organization performance in Kenya's horticultural sector. This study was carried out in flower farms in Kenya. The population of this study was all flower farms in Kenya which were the 14 flower farms registered in the KFC directory (2013) and based in Naivasha. The study targeted the employees in the identified farms. Cross sectional survey research design was used for the study. Stratified sampling technique was used to sample the study respondents. A total of 2460 respondents were targeted by the study out of which 1888 responded giving a response rate of $76.7 \%$. Questionnaires were used as instrument for data collection. Both quantitative and qualitative data analysis techniques were used. Quantitative data was analyzed using descriptive statistics while qualitative data was analyzed thematically. Inferential statistics such as correlation and regression analysis were used to test on the relationship between the variables of the study. The study found that $55 \%$ of the respondents agreed that there were clear policy on staff supervision and performance development. It was also found that $55 \%$ of the respondents agreed that there are clear guidelines on time for reporting to work and leaving. The results of correlation analysis show that employee engagement is statistically significant with a Pearson correlation coefficient of 0.533 at a level of significance of 0.000 . The study concluded that employee engagement is a major determinant of organization performance in the horticultural sector in Kenya. The study recommended that organization should emphasize on induction training as it will help in clarifying the roles of employees thus improving the general organization performance.
\end{abstract}

Keywords: employee engagement, organization performance

\section{Introduction}

The history of the export of fresh horticultural produce from Kenya dates back to the period before independence when Kenya, then a British colony, was required to contribute to the running of the budget for East Africa. After independence the industry continued to flourish with exports starting to go to Europe and thus opening up the potential for Kenya in the export market (Maplecroft, 2010). Kenya is primarily an agricultural economy. Agriculture plays a critical role in national economic growth and development. The major roles of agriculture include; employment, foreign exchange creation and overall contribution to Gross Domestic Product (GDP).

Agriculture accounts for about $24 \%$ of Kenya's GDP with an estimated $75 \%$ of the population depending on the sector either directly or indirectly (Maplecroft, 2010). Agriculture is the mainstay of the Kenyan economy and currently represents 24 per cent of GDP. More than one-third of Kenya's agricultural produce is exported, and this accounts for sixty five per cent of Kenya's total exports (Dolan, 2004). The agricultural sector accounts for eighteen per cent of total formal employment in the country. The Cut-Flower Industry has been active in Kenya since the 1980's, but only in the 1990's has it transformed into a major player in the international market.

Several factors made Kenya attractive for growing flowers: a cheap and relatively educated labour force, suitable climate conditions and proximity to Europe's big markets. These factors attracted capital and the knowledge needed for boosting the industry (Maplecroft, 2010). Today, the Cut-Flower Industry is the fastest growing segment in Kenya. It is also the largest export industry in the country responsible for annual turnover of nearly 600 Million Dollars. Kenya is 
the fifth largest flower exporter in the world. It exports primarily to the Netherlands, Germany and the U.K. The development of the flower industry in Kenya is an example of regional economic development that exploits comparative advantages to export to developed markets (Derek, 2005).

Companies in the horticultural sector are now increasingly coming under pressure to ensure decent working conditions for their workers. The horticulture sector is under threat from the above factors and it is imperative that attention must be shifted to address the labour relations practices in this industry since competitiveness in this sector if it is to remain the mainstream of foreign exchange earnings for the government and continue creating employment for the country. This research explored the effect of employee engagement on organization performance in Kenya's horticultural sector.

\subsection{Statement of the Problem}

The horticulture sector is estimated to employ over 50,000-60,000 people directly and 500,000 people indirectly through affiliated services to the industry for example farm inputs, transport, packaging and banking (Kenya Flower Council, 2010). It is therefore imperative that the welfare of the workers working in this sector is given paramount importance by both government and the stakeholders as a whole.

According to Maplecroft (2010), there have been poor human resource management practices in the horticultural sector as a result of companies ignoring labour relations practices. Some of these poor practices include unethical labour practices, for example dismissal of workers, without proper reasons and denying them the freedom of association by refusing them to join trade unions. The horticultural sector is now increasingly coming under pressure to ensure decent working conditions for their workers.

A research by Dolan (2004) focused on poor labour practices and environmentally damaging production processes without getting into the reason why employers were guilty of such poor practices and the effect that arose to both employees and employers as a result of such actions. Suffice to say the researcher tried to analyze how ethical trade can enhance the economic and social rights of women and men in African export Horticulture and identifying best practice in implementing gender sensitive ethical trade based on worker and stakeholder participation.Collinson (2010) research mainly focused on the gains of labour productivity and management efficiency arising from implementation of social codes in a company. Again, it did not analyze the relationship between labour relations practices in the horticulture sector. Other researchers (Omwega, 2007; Riungu, 2006; Riungu, 2007; Barrientos et al., 2003; Opondo et al, 2003; Opondo et al, 2005; Utting, 2002) have also researched on various areas within the flower industry including gender rights, multi stakeholder participation and working conditions in the industry. Going through these researches there is a gap on the relationship between labour relations practices in the horticulture sector. This study therefore sought to explore the effect of employee engagement on organization performance in Kenya's horticultural sector.

\section{Literature Review}

This section presents theoretical and empirical review.

\subsection{Human Capital Theory}

The concept of Human capital has relatively more importance in labour-surplus countries. These countries are naturally endowed with more of labour due to high birth rate under the given climatic conditions (House, 1996). The surplus labour in these countries is the human resource available in more abundance than the tangible capital resource. According to Kelly (2007) this human resource can be transformed into human capital with effective inputs of education, health and moral values. The transformation of raw human resource into highly productive human resource with these inputs is the process of human capital formation. The problem of scarcity of tangible capital in the labour surplus countries can be resolved by accelerating the rate of human capital formation with both private and public investment in education and health sectors of their National economies.

The tangible financial capital is an effective instrument of promoting economic growth of the nation. The intangible human capital, on the other hand, is an instrument of promoting comprehensive development of the nation because human capital is directly related to human development, and when there is human development, the qualitative and quantitative progress of the nation is inevitable. Human capital is the stock of competencies, knowledge, social and personality attributes, including creativity, cognitive abilities, embodied in the ability to perform labor so as to produce economic value. It is an aggregate economic view of the human being acting within economies, which is an attempt to capture the social, biological, cultural and psychological complexity as they interact in explicit and/or economic transactions (Rosen, 1987).

Many theories explicitly connect investment in human capital development to education, and the role of human capital in economic development, productivity growth, and innovation has frequently been cited as a justification for government subsidies for education and job skills training. There is also strong evidence that organizations that possess 
and cultivate their human capital outperform other organizations lacking human capital (Crook, Todd, Combs, Woehr, and Ketchen, 2011). This study assessed the relevance of this theory in relation to the organisational performance of Kenya's horticultural sector which is very labour intensive.

\subsection{Path Goal Theory}

The path-goal theory, also known as the path-goal theory of leader effectiveness or the path-goal model, is a leadership theory developed by Robert House (1996). The theory states that a leader's behavior is contingent to the satisfaction, motivation and performance of her or his subordinates. The revised version also argues that the leader engages in behaviors that complement subordinate's abilities and compensate for deficiencies. The path-goal model can be classified as a transaction leadership theory.

According to the first of all theory, the manager's job is viewed as guiding workers to choose the best paths to reach their goals, as well as the organizational goals. The theory argues that leaders will have to engage in different types of leadership behavior depending on the nature and the demands of a particular situation. It is the leader's job to assist followers in attaining goals and to provide the direction and support needed to ensure that their goals are compatible with the organization's goals (Crook, Todd, Combs, Woehr, and Ketchen, 2011).

A leader's behavior is acceptable to subordinates when viewed as a source of satisfaction and motivational when need satisfaction is contingent on performance, and the leader facilitates, coaches, and rewards effective performance. The original path-goal theory identifies achievement-oriented, directive, participative, and supportive leader behaviors:The directive path-goal clarifying leader behavior refers to situations where the leader lets followers know what is expected of them and tells them how to perform their tasks. The theory argues that this behavior has the most positive effect when the subordinates' role and task demands are ambiguous and intrinsically satisfying (Peter, 1997). The achievement-oriented leader behavior refers to situations where the leader sets challenging goals for followers, expects them to perform at their highest level, and shows confidence in their ability to meet this expectation. Occupations in which the achievement motives were most predominant were technical jobs, sales persons, scientists, engineers, and entrepreneurs (Peter, 1996).

The participative leader behavior involves leaders consulting with followers and asking for their suggestions before making a decision. This behavior is predominant when subordinates are highly personally involved in their work (Peter, 1996).The supportive leader behavior is directed towards the satisfaction of subordinates needs and preferences. The leader shows concern for the followers' psychological well being. This behavior is especially needed in situations in which tasks or relationships are psychologically or physically distressing (Peter, 1996).

Path-goal theory assumes that leaders are flexible and that they can change their style, as situations require. The theory proposes two contingency variables, such as environment and follower characteristics, that moderate the leader behavior-outcome relationship. Environment is outside the control of the follower-task structure, authority system, and work group. This theory will go to support the variable on leadership styles (Cole, 2002). This theory of leadership will be tested against the variable on democratic leadership style and its effect on labour relations and organizational performance.

\subsection{Empirical Literature}

Biloch and Lofstedt (2013) created a model that promotes employee engagement partially based on established concepts within performance management and motivation and partially based on a pioneer concept within business, referred to as gamification. The aim of their study was to adapt this model to an organizational setting characterized as potentially unengaging to be able to identify possible benefits and concerns with the model developed. The data collection was done through a case study involving both qualitative semi-structured interviews and observations with professionals within haulage firms. The model created was thereafter configured to the work situation of a truck driver, in order to illustrate how employee engagement can be promoted within haulage firms. An important finding of this thesis is that each component of the performance management cycle can, to various extents, be supported by game elements to drive employee engagement within the performance management process. It has also been found that this model can be adapted to different work situations on the basis of the appropriate style of management control and a means-ends analysis of the constituent game elements that underlie the model. Moreover, this thesis propose how haulage firms, through this model, can promote employee engagement and thereby an opportunity to command a source of competitive advantage. This study therefore sought to explore the effect of employee engagement on organization performance.

AbuKhalifeh and Ahmad (2013) studied the antecedents that influence employee engagement in food and beverage service department. Literature reviewed indicated that there is a significant relationship between employee communication, employee development, rewards and recognition, and extended employee care. Among the 
antecedents, employee development forms the most significant contributor. The study concluded that employee engagement for the food and beverage department in the hotel industry is highly significant to the hotel industry. The literature shows that the antecedents of employee engagement influence employee engagement and have a significant impact on the level of engagement among employees. The findings also indicate that employee development is the highest contributing factor to employee engagement. Hence, it is important for hotels to increase the level of engagement among their employees as an investment in employee development. Spending more on programs that develop the skills of the F\&B employees by carrying out suitable workshops and training curriculum that enhances skills and improves the service performed is highly beneficial for hotels. This study was done in horticultural sector to assess how the antecedents that influence employee engagement influences organization performance.

Miller (2008) carried out an assessment on employee engagement in XYZ Company. Data was collected data from the production employees at XYZ Manufacturing Company, on employee engagement. Production employees were asked to fill out a Q-12 survey developed by the Gallup organization to measure employee engagement (Buckingham and Coffinan, 1999). This data was collected and analyzed in order to show the level of employee engagement within the production employees of XYZ Manufacturing Company. XYZ Manufacturing Company is a suspension manufacture company. There are 239 production employees in assembly manufacturing. A total of 169 surveys were returned which is a $70.2 \%$ return rate. The survey sample of the production employees was chosen because these are the employees that have the greatest influence on the production, quality, and changes in the current systems. Employee engagement is a key driver for organizational success. High levels of engagement promote retention of talent, foster customer loyalty, and improve organizational performance. Engagement is influenced by many factors: workplace culture, communication, managerial styles, trust and respect (Lockwood, 2007). This study was carried in the manufacturing where organization performance was one of the indicators. In this study, the focus was to assess how different aspects of employee engagement impacts of organization performance.

Bakar (2013) examined the factors that influence and shape employee engagement in the context of the financial sector in Malaysia. It does this by studying multilevel factors at three levels, the individual, organizational and societal levels. Specifically, the thesis focuses on three increasingly prominent concepts: empowering leaders' behaviour, high performance work practices (HPWP) and the possible role of religiosity. Drawing on institutional theory, an important argument in this thesis is the limitation of the mainstream single-level conceptualizations of employee engagement, which fail to capture the relational interplay of the contextual factors and the multilevel nature of engagement. Earlier research in HRM, particularly on employee engagement, has been conducted primarily from a micro-perspective that has focused on a specific function with little acknowledgement of contextual setting. This study uses a framework that bridges the macro- and microinstitutional levels of analysis in understanding employee engagement. To achieve this objective, this study adopted a mixed-method approach. The first method, a qualitative study of 41 interviews with employees in the financial sector, was designed to explore the most salient factors in the employees' levels of engagement. The secondmethod, a quantitative survey of 278 employees, was designed to investigate the associations between the studied variables. Findings from both analyses suggest that empowering leadership behaviour has the largest effect on employee engagement. In particular, employees experience a significant level of engagement when their leader shows concern. At the organizational level, HPWP do seems to be practiced in the organizations and to have an effect on engagement. However, problems that occur within the organizations cause the ineffectiveness of HPWP implementation. Interestingly, religiosity was found to play a crucial role in engaging employees at work among the Malay Muslims. This study was carried out in the financial sector where the focus was on factors influencing employee engagement. This study focused on how employee engagement influences the general organization performance.

\section{Methodology}

This study was carried out in flower farms in Kenya. The population of this study was all flower farms in Kenya which were the 14 flower farms registered in the KFC directory (2013) and based in Naivasha. The study targeted the employees in the identified farms. Cross sectional survey research design was used for the study. Stratified sampling technique was used to sample the study respondents. A total of 2460 respondents were targeted by the study out of which 1888 responded giving a response rate of $76.7 \%$. Questionnaires were used as instrument for data collection. Both quantitative and qualitative data analysis techniques were used. Quantitative data was analyzed using descriptive statistics while qualitative data was analyzed thematically. Inferential statistics such as correlation and regression analysis were used to test on the relationship between the variables of the study.

Multiple regression model presented below was used

$$
Y=\beta_{0}+\beta_{1} X_{1}+\beta_{2} X_{2}+\beta_{3} X_{3}+\beta_{1} X_{1} Z+\varepsilon
$$

Where 
$\mathrm{Y}=$ is the dependent variable (Organizational performance)

$\mathrm{Z}=$ Leadership styles

$\mathrm{Xi}=$ is the three independent variables i.e. employee communication, employee involvement and human resources procedures where $(\mathrm{i}=1,2, \ldots . \mathrm{n})$

$\mathrm{X}_{1=}$ Employee communication

$\mathrm{X}_{2}=$ Employee engagement

$\mathrm{X}_{3}=$ Human resource procedures

$\mathrm{Z}=$ product term between moderating variables and each independent term

$\beta_{i(i=1,2,3,4)}$ are the parameters associated with the corresponding independent variable that are to form part of the partial regression coefficients

$\beta_{\mathrm{o}}$ is the intercept

$\varepsilon$ is the error term

\section{Findings of the Study}

The study adopted factor analysis in order to reduce the number of indicators or factors under each research variable and retain the indicators capable of explaining the responses to globalization adopted by manufacturing firms in Kenya. The retained factors had loading values of above 0.4 and were used for further analysis.

To measure the reliability of the gathered data, Cronbach's alpha was used. Cronbach's alpha is a coefficient of reliability that gives an unbiased estimate of data generalizability (Zinberg, 2005). An alpha coefficient of 0.70 or higher indicated that the gathered data is reliable as it has a relatively high internal consistency and can be generalized to reflect opinions of all respondents in the target population (Zinbarg, 2005). Table 1 shows Cronbach's alpha of all indicators. Cronbach's alpha results in the component column were computed using the results of all indicators. The results revealed that ten out of 11 indicators/factors had a loading of more than 0.4.

Table 1. Factor analysis for employee engagement indicators

\begin{tabular}{lllc}
\hline $\begin{array}{l}\text { Cronbach's Alpha } \\
\text { before }\end{array}$ & Component & $\begin{array}{c}\text { Cronbach Alpha } \\
\text { after }\end{array}$ \\
\hline .881 & $\begin{array}{l}\text { I have the materials and equipment I need to do } \\
\text { my job right. }\end{array}$ & .826 & .887 \\
\hline & $\begin{array}{l}\text { I received recognition or praise for doing good } \\
\text { work }\end{array}$ & .801 & .769 \\
\hline I have a best friend at work. & .769 \\
\hline $\begin{array}{l}\text { My supervisor, or someone at work, seems to care } \\
\text { about me as a person }\end{array}$ & .723 \\
\hline $\begin{array}{l}\text { In the last six months, someone at work has talked } \\
\text { to me about my progress. }\end{array}$ & .644 \\
\hline $\begin{array}{l}\text { At work, my opinions seem to count } \\
\text { I know what is expected of me at work. }\end{array}$ & .593 \\
\hline $\begin{array}{l}\text { There is someone at work who encourages my } \\
\text { development. }\end{array}$ & .593 \\
\hline $\begin{array}{l}\text { This last year, I have had opportunities at work to } \\
\text { learn and grow. }\end{array}$ & $\begin{array}{l}\text { My associates or fellow employees are committed } \\
\text { to doing quality work }\end{array}$ \\
\hline $\begin{array}{l}\text { The mission or purpose of my company makes me } \\
\text { feel my job is important }\end{array}$ & .336 \\
\hline
\end{tabular}


Table 1 shows that Cronbach's alpha result of all employee engagement indicators was 0.881 and the factor loading results were between 0.336 and 0.826 . This implies that ten of the eleven indicators were retained for further analysis. Using the retained employee engagement indicators, the value of Cronbach's alpha was computed again and generated a value of 0.887 . This indicated that data collected using all the employee engagement indicator values were reliable since the Cronbach's alpha value was above 0.70 . These indicators were later used for further analysis.

Descriptive statistics were used to describe the basic features of the data in the study. They provide simple summaries of the sample and measures. Descriptive statistics such as frequencies and percentages were used to analyze the data. Table 2 presents the findings on the effect of employee engagement on organization performance.

Table 2. Effect of employee engagement on organization performance

\begin{tabular}{|c|c|c|c|c|c|}
\hline Statement & $\begin{array}{l}\text { Strongly } \\
\text { disagree }\end{array}$ & Disagree & $\begin{array}{c}\text { Neither } \\
\text { agree nor } \\
\text { disagree }\end{array}$ & Agree & $\begin{array}{c}\text { Strongly } \\
\text { agree }\end{array}$ \\
\hline $\begin{array}{l}\text { Employees are well aware of their roles and } \\
\text { responsibilities in the organization }\end{array}$ & $0 \%$ & $10 \%$ & $20 \%$ & $30 \%$ & $40 \%$ \\
\hline $\begin{array}{l}\text { There is a clear policy on health and safety } \\
\text { procedures in the organization }\end{array}$ & $0 \%$ & $0 \%$ & $25 \%$ & $45 \%$ & $30 \%$ \\
\hline $\begin{array}{l}\text { There is clear policies and processes for } \\
\text { recruitment of staff in the organization }\end{array}$ & $0 \%$ & $5 \%$ & $20 \%$ & $40 \%$ & $35 \%$ \\
\hline There is clear staff exit procedures & $0 \%$ & $15 \%$ & $25 \%$ & $25 \%$ & $35 \%$ \\
\hline $\begin{array}{l}\text { There is a clear policy on staff supervision } \\
\text { and performance development }\end{array}$ & $0 \%$ & $5 \%$ & $15 \%$ & $55 \%$ & $25 \%$ \\
\hline $\begin{array}{l}\text { There are clear procedures for carrying out } \\
\text { staff appraisals within the organization }\end{array}$ & $10 \%$ & $10 \%$ & $15 \%$ & $34 \%$ & $31 \%$ \\
\hline $\begin{array}{l}\text { There is a policy on staff training and } \\
\text { development }\end{array}$ & $0 \%$ & $0 \%$ & $20 \%$ & $30 \%$ & $50 \%$ \\
\hline $\begin{array}{l}\text { There are clear guidelines on time for } \\
\text { reporting to work and leaving }\end{array}$ & $5 \%$ & $5 \%$ & $15 \%$ & $55 \%$ & $20 \%$ \\
\hline $\begin{array}{l}\text { There are clear codes of conduct in the } \\
\text { organization }\end{array}$ & $5 \%$ & $0 \%$ & $41 \%$ & $31 \%$ & $23 \%$ \\
\hline $\begin{array}{l}\text { Security is provided within the work } \\
\text { environment in the organization. }\end{array}$ & $0 \%$ & $10 \%$ & $25 \%$ & $32 \%$ & $33 \%$ \\
\hline
\end{tabular}

Table 2 shows that $55 \%$ of the respondents agreed that there were clear policy on staff supervision and performance development. It was also found that $55 \%$ of the respondents agreed that there are clear guidelines on time for reporting to work and leaving. The findings further revealed that $50 \%$ of the respondents strongly agreed that there was a clear policy on staff training and development, $45 \%$ agreed that there was clear policy on health and safety procedures in the organization and that $40 \%$ agreed that there is clear policies and processes for recruitment of staff in the organization.

\subsection{Correlation Analysis}

This study conducted correlation analysis to test on the strength of association/relationship between the study variables. Correlation is a measure of the relationship or association between two continuous numeric variables. It indicates both the direction and degree to which they vary with one another from case to case without implying that one is causing the other. Correlation analysis results give a correlation coefficient which measures the linear association between two variables (Crossman, 2013).

\section{Employee Engagement correlation analysis}

The symmetric matrix with Pearson correlations given in Table 3 shows that the Pearson correlation coefficient was 0.533 and this demonstrates that employee engagement have a positive correlation with globalization. 
Table 3. Employee engagement and organization performance

\begin{tabular}{llcc}
\hline \multicolumn{4}{c}{ Correlations } \\
& \multicolumn{1}{c}{ Employee engagement } & $\begin{array}{c}\text { Organization } \\
\text { Performance }\end{array}$ \\
\hline \multirow{3}{*}{ Employee engagement } & Pearson Correlation & 1 & $.533^{* *}$ \\
\cline { 2 - 4 } & Sig. (2-tailed) & 1888 & .000 \\
\cline { 2 - 4 } & $\mathrm{N}$ & $.533^{* *}$ & 1888 \\
\hline \multirow{3}{*}{ Organization Performance } & Pearson Correlation & .000 & 1888 \\
\cline { 2 - 4 } & Sig. (2-tailed) & 1888 & \\
\hline & $\mathrm{N}$ & & \\
\hline
\end{tabular}

\subsection{Regression Analysis}

\section{Regression Analysis on Employee Engagement and Organization Performance}

Regression analysis was done to determine the relationship between employee engagement and organization performance

Table 4 shows that the coefficient of determination $\mathrm{R}$ square is 0.284 and $\mathrm{R}$ is 0.533 at 0.05 significant level. The coefficient of determination indicates that $28.4 \%$ of the variation in the response to organization performance is explained by employee engagement.

Table 4. Model summary

\begin{tabular}{|c|c|c|c|c|}
\hline \multicolumn{5}{|c|}{ Model Summary } \\
\hline Model & $\mathrm{R}$ & R Square & Adjusted R Square & Std. Error of the Estimate \\
\hline 1 & $.533^{\mathrm{a}}$ & .284 & .284 & .823 \\
\hline
\end{tabular}

a. Predictors: (Constant), Employee engagement

Table 5 presents the results of Analysis of Variance (ANOVA) on employee engagement versus organization performance. The ANOVA results for regression coefficient indicates that the significance of the $\mathrm{F}$ is 0.00 which is less than 0.05 hence implying that there is a positive significant relationship between employee engagement and organization performance.

Table 5. Anova

\begin{tabular}{llrrrrr}
\hline \multicolumn{7}{c}{ ANOVA $^{\mathbf{a}}$} \\
\hline Model & \multicolumn{7}{c}{ Sum of Squares } & df & Mean Square & F & Sig. \\
\hline \multirow{3}{*}{1} & Regression & 253.753 & 1 & 253.753 & 374.275 & $.000^{\text {b }}$ \\
\cline { 2 - 7 } & Residual & 1784.538 & 1886 & .678 & \\
\cline { 2 - 7 } & Total & 1784.828 & 1887 & & & \\
\hline
\end{tabular}

a. Dependent Variable: Organization Performance

b. Predictors: (Constant), Employee engagement

Further analysis was done to determined beta coefficients of employee communication versus organization performance. Table 6 shows that there is significant relationship between employee communication and organization performance. Since the coefficient of adoption of technology is 0.614 which is statistically greater than zero. The $t$ statistic is 19.346 which is greater than zero. This demonstrates that employee engagement have a positive influence on organization performance. 
Table 6. Coefficients

\begin{tabular}{|c|c|c|c|c|c|c|}
\hline \multicolumn{7}{|c|}{ Coefficients $^{\mathrm{a}}$} \\
\hline \multirow[t]{2}{*}{ Model } & & Unstandardized & oefficients & Standardized & $\mathrm{t}$ & Sig. \\
\hline & & B & Std. Error & Beta & & \\
\hline \multirow{2}{*}{1} & (Constant) & 1.631 & .138 & & 11.858 & .000 \\
\hline & Employee engagement & .614 & .032 & .533 & 19.346 & .000 \\
\hline
\end{tabular}

a. Dependent Variable: Organization Performance

\section{Discussion}

The factor analysis results on employee engagement had an Alpha of 0.881 and the loading results between 0.336 and 0.826. Using the retained employee engagement indicators, the value of Cronbach's alpha was computed again and generated a value of 0.887 . The study therefore deduced that ten out of the eleven indicators of employee engagement were reliable in assessing the effect of employee engagement on organization performance. Employee engagement indicators such as availability of materials and equipment, recognition and praise, friendship at work, supervision on progress at work, opinion count, role awareness, motivation and encouragement and job commitment were later used for further analysis.

Descriptive statistics results showed that employee engagement is one of the strategies by organizations in the horticultural sector to improve their performance. This is evidenced by $68 \%$ of the respondents indicated that they knew what is expected of them at work. The finding is in line with that of Sani (2012) who found that strategic HRM alignment, line management training, career planning system and job definition are the key strategic HR practices that influence organizational performance in the Nigerian insurance industry. Results also suggest that the relationship between strategic HRM practices and organizational performance in the Nigerian insurance industry is moderately influenced by organizational climate.

The study also found that $67 \%$ indicated that someone at work who encourages their development. The findings further revealed that $67 \%$ of the respondents agreed that they had an opportunity to learn and grow in the organization over the past one year. These findings corroborates with that of Nassazi (2013) who found that training have a clear effect on the performance of employees.

Pearson correlation analysis of employee engagement results gave a correlation of 0.533 which demonstrated that employee engagement has a positive correlation with organization performance. Regression model of employee engagement versus organization performance gave a coefficient of determination of $\mathrm{R}$ square of 0.284 and $\mathrm{R}$ as 0.533 at 0.05 significant level. The coefficient of determination indicated that $28.4 \%$ of the organization performance is explained by employee engagement. This implies that there exists a strong positive relationship between employee engagement and organization performance.

\section{Summary of Findings}

Employee engagement is one of the strategies by organizations in the horticultural sector to improve their performance. The study found that $68 \%$ of the respondents indicated that they knew what is expected of them at work. The study also found that $67 \%$ indicated that someone at work who encourages their development. The findings further revealed that $67 \%$ of the respondents agreed that they had an opportunity to learn and grow in the organization over the past one year, $61 \%$ of the respondents strongly agreed that their associates or fellow employees are committed to doing quality work and $57 \%$ agreed that they are recognized or praise for doing good work.

The findings from the correlation analysis revealed that organization performance is positively related with the employee engagement with a Pearson's correlation coefficient of $r=0.533$ and at a level of significance of 0.000 , an indication that employee engagement is statistically significant with $p$ value less than 0.05

\section{Conclusions}

Employee engagement was found to encourage employee development thus affecting the general organization performance. This is based on the fact that when employees are motivated and also given opportunity to participate in decision making processes, they became committed to their work. 


\section{Recommendations}

The study also recommends that organization should emphasize on induction training. This will help in clarifying the roles of employees thus improving the general organization performance.

\section{Limitations of the Study}

One of the limitations of this study is that it only focused on employee engagement which is one of the determinants of organization performance. Thus, the study left out other determinants of organization performance.

\section{References}

AbuKhalifeh, A., \& Ahmad, P. (2013). The Antecedents Affecting Employee Engagement and Organizational Performance. Asian Social Science, 9(7). Published by Canadian Center of Science and Education.

Bakar, R.A. (2013). Understanding Factors Influencing Employee Engagement: A Study of the Financial Sector in Malaysia. Published thesis, RMIT University.

Barrietos, S., Dolan.C., \& Tallontire, A. (2003). A gendered value chain approach to codes of conduct in Africa Horticulture.

Basbous, O.K. (2011). Antecedents of employee engagement. Published thesis, University of Malaysia.

Biloch, A., \& Lofstedt, A. (2013). Gamification and performance management: A tool for driving competitiveness through employee Engagement. Published thesis. Luleå University of Technology.

Collinson, C. (2001). The business Costs of ethical supply chain management: Kenya Flower Industry Case Study. NRI Report No.2607, project code: VO128.

Crossman, A. (2013). Convergence theory. About.com sociology. Retrieved December 04, 2013, from $\mathrm{http}: / /$ sociology.about.com/od/C_Index/g/Convergence-Theory.htm

Dolan, C. (2004). Seeking Common Ground' Multi stakeholder initiatives in Kenya Cut Flower Industry. Journal of Corporate Citizenship on Africa.

Keeley, M. P. (2007). “Turning toward death together:” The functions of messages during final conversations in close relationships. Journal of Social and Personal Relationships, 24, 225-253.

Maplecroft, B. (2010). Labour standards and Environmental Report, Q3. Maplecroft, Human rights monitoring, Maplecroft.

Miller, S.L. (2008). An Employee Engagement Assessment of XYZ Manufacturing Company. Published thesis, The Graduate School University of Wisconsin-Stout.

Omwenga, B. (2007). Kenya's Competiveness in the Floriculture Industry: A Test of Porters Competitive Advantage of Nations nodel.

Riungu, C. (2006). A thorn on every rose for Kenya's flower industry. The East African, Nairobi, February 21.

Riungu, C. (2007). Flower exports Flourish despite odds. The East African, Nairobi, May 21.

Sakovska, M. (2012). Importance of Employee Engagement in Business Environment: Measuring the engagement level of administrative personnel in VUC Aarhus and detecting factors requiring improvement. Published thesis, Aarhus University.

Utling. (2002). Regulating Business via Multi stakeholder Initiatives: A Preliminary Assessment.

Zinbarg, M. (2005). Research Methods (2 ${ }^{\text {nd }}$ ed.). Pearson Publishers. 